Open Access

\title{
Pappa2 deletion in mice affects male but not female fertility
}

\author{
Julian K. Christians", Avery Y. King, Monika D. Rogowska and Sonia M. Hessels
}

\begin{abstract}
Background: Recent studies have found associations between the gene encoding pregnancy associated plasma protein-A2 (PAPP-A2), a protease of insulin-like growth factor binding protein -5 (IGFBP-5), and measures of female reproductive performance in cattle. The purpose of the present study was to test the effects of Pappa2 deletion on reproduction in mice.

Findings: We measured the fertility and offspring growth of Pappa2 deletion females, and also performed reciprocal matings (i.e., deletion males mated to control females) to control for the effects of offspring genotype. Ovarian and testicular IGFBP-5 levels were measured by Western blotting. As expected, deletion of Pappa2 increased ovarian IGFBP-5 levels. However, Pappa2 deletion in females had no effect on the interval between pairing and the birth of the first litter, the interval between the births of the first and second litters, or litter size. Offspring weight was lower in the offspring of Pappa2 deletion females, but effects of similar magnitude were observed in the offspring of Pappa2 deletion males, suggesting that the effects were due to heterozygosity for the deletion in the offspring. Pappa2 deletion in males had no effect on litter size or the interval between pairing and the birth of the first litter. However, the interval between the births of the first and second litters was significantly longer in deletion males.
\end{abstract}

Conclusions: Pappa2 deletion had no effect on female reproductive performance. In contrast, Pappa2 deletion had subtle effects on male fertility, although the underlying mechanism remains to be elucidated.

Keywords: Pappalysin-2, Insulin-like growth factor, Insulin-like growth factor binding protein, Ovary, Fertility

\section{Findings}

\section{Background}

Insulin-like growth factors (IGFs) and their binding proteins (IGFBPs) contribute to the regulation of ovarian function in mammals [1]. IGFBPs, in turn, are regulated by proteolysis [2]. Pregnancy associated plasma proteinA2 (PAPP-A2) is a protease of IGFBP-5 [3] that has been studied in the contexts of pregnancy [4-7] and postnatal growth [8-10], but not ovarian function. However, a number of recent studies have found associations between the bovine PAPP-A2 gene and rebreeding interval $[11,12]$, pregnancy rate [13], and age at first and second calving [14]. Furthermore, a paralog of PAPP-A2, PAPP-A, contributes to proteolytic degradation of IGFBP-2, IGFBP4 and IGFBP- 5 that is associated with follicular growth, whereas increased intrafollicular levels of IGFBPs are

\footnotetext{
*Correspondence: julian_christians@sfu.ca

Department of Biological Sciences, Simon Fraser University, 8888 University Drive, Burnaby, BC V5A 156, Canada
}

(c) 2015 Christians et al. Open Access This article is distributed under the terms of the Creative Commons Attribution 4.0 International License (http://creativecommons.org/licenses/by/4.0/), which permits unrestricted use, distribution, and reproduction in any medium, provided you give appropriate credit to the original author(s) and the source, provide a link to the Creative Commons license, and indicate if changes were made. The Creative Commons Public Domain Dedication waiver (http://creativecommons.org/publicdomain/zero/1.0/) applies to the data made available in this article, unless otherwise stated. Pappa deletion mice [15] and mice overexpressing Igfbp5 [16] suggesting that PAPP-A2 may play a role in fertility as well. In addition to its potential roles in ovarian function, PAPP-A2 has been associated with milk yield in cattle [13]. PAPP-A2 might influence lactation performance since IGFBP-5, a PAPP-A2 substrate, plays a role in mammary gland development [17], and mammaryspecific expression of $I g f b p 5$ reduced milk production in mice [18].

To investigate the roles of PAPP-A2 in fertility and lactation, we examined the effects of Pappa2 gene deletion in mice. Pappa2 deletion mice are smaller than wild-type [9], and since the offspring of deletion females and control males would be heterozygous for the deletion, we expected them to be smaller than the offspring of control females and males. We therefore also examined reciprocal matings (i.e., deletion males and control females) to control for the effect of offspring genotype, 
independent of the maternal genotype. Since PAPP-A2 is a protease of IGFBP-5, we also tested whether Pappa2 deletion increases the ovarian levels of IGFBP-5, as it does the circulating levels of IGFBP-5 [19].

\section{Methods}

\section{Pappa2 deletion mice}

All work was carried out in accordance with the guidelines of the Canadian Council on Animal Care and approved by the SFU University Animal Care Committee (protocol 1035B-11). Pappa2 deletion mice with a C57BL/6 background were generated as previously described $[9,19]$ The intact conditional allele (Pappa $2^{f l}$ ) was used as the control for the deletion allele (Pap$\left.p a 2^{K O}\right)$; there is no difference in postnatal weight gain between mice homozygous for the Pappa $2^{f l}$ allele and littermates homozygous for the wild-type allele [19]. Mice were ear-clipped at weaning and PCR genotyping was performed as previously described [19].

\section{Matings}

Females or males homozygous for the deletion allele $\left(\right.$ Pappa $\left.2^{K O / K O}\right)$ or the intact conditional allele (Pappa $2^{f l / f l}$ ) were paired with mice with two intact alleles. Following pairing, cages were checked every morning, and newborn pups were counted. Litters with evidence of cannibalization were included in analyses of time to birth, but not in analyses of litter size. At three weeks pups were sexed and weighed.

\section{Western blotting}

Virgin mice were culled at approximately 19 weeks of age (i.e., the age at which the mice in the breeding experiments were paired) to collect ovaries and testes. Protein extraction and Western blotting were performed as described previously [9] using a $12.5 \%$ polyacrylamide gel for separation and a primary antibody solution containing 1:1000 monoclonal mouse anti-actin (CLT9001; Cedarlane, Burlington ON) and 1:500 polyclonal goat-
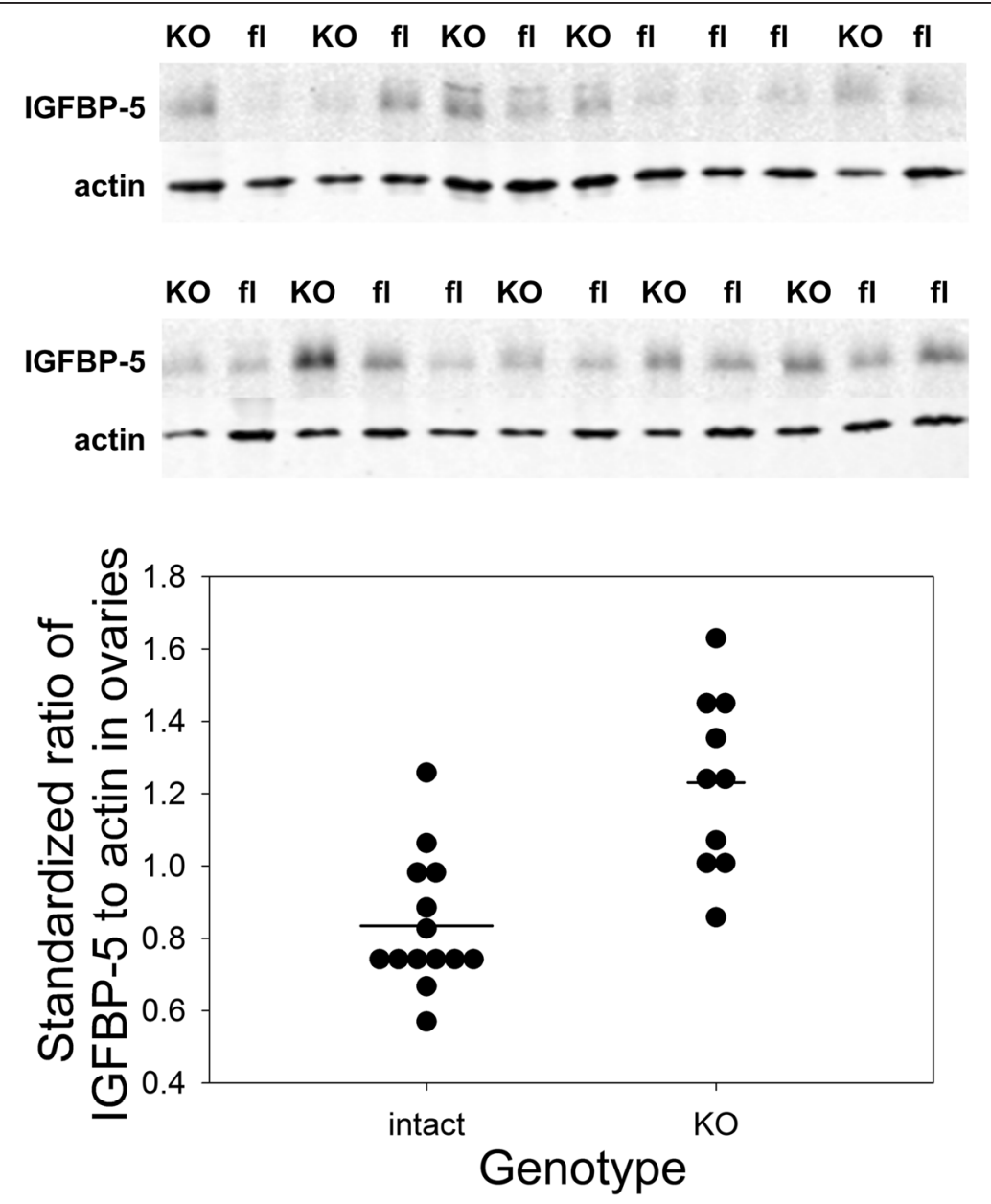

Fig. 1 Ovarian IGFBP-5 levels, measured by Western blotting. Upper: Western blotting of IGFBP-5 and actin in the ovaries of females homozygous for the deletion allele (Pappa2 ${ }^{\mathrm{KO} / \mathrm{KO}} ; \mathrm{KO}$ ) or the intact conditional allele (Pappa2 $2^{f / / f l}$; fl). Lower: Ratio of the intensity of the IGFBP-5 band to that of the actin band, standardized by dividing an individual sample's ratio by the mean ratio of all samples on the same blot, such that the average value is 1 . Horizontal lines represent the means for each group 
Table 1 Reproductive traits of mice homozygous for Pappa2 disruption (Pappa2 ${ }^{K O / K O}$ ) or homozygous for the intact allele (Pappa2 $2^{f / f l}$ )

\begin{tabular}{|c|c|c|c|c|c|c|}
\hline & \multicolumn{3}{|l|}{ Females } & \multicolumn{3}{|l|}{ Males } \\
\hline & Pappa2 fl/fl & Pappa2 $2^{K O / K O}$ & P-value ${ }^{a}$ & Pappa $2^{f l / f l}$ & Pappa2 $2^{K O / K O}$ & $P$-value ${ }^{a}$ \\
\hline $\bar{N}$ & 15 & 17 & & 6 & 10 & \\
\hline Mass at pairing $(\mathrm{g})$ & $23.5 \pm 0.5$ & $20.7 \pm 0.4$ & 0.0001 & $30.5 \pm 0.7$ & $24.6 \pm 0.5$ & 0.0001 \\
\hline Age at pairing (weeks) & $19.5 \pm 0.4$ & $19.4 \pm 0.4$ & 0.80 & $19.5 \pm 0.8$ & $19.4 \pm 0.6$ & 0.97 \\
\hline Days between pairing and birth of first litter & $27.0 \pm 2.0$ & $24.0 \pm 1.9$ & 0.28 & $25.3 \pm 2.2$ & $22.3 \pm 1.7$ & 0.28 \\
\hline Days between births of first and second litters & $30.6 \pm 1.1$ & $26.7 \pm 1.1$ & 0.11 & $23.1 \pm 1.1$ & $38.8 \pm 1.1$ & 0.0001 \\
\hline $\begin{array}{l}\text { Proportion of matings that produced second litter within } \\
35 \text { days of birth of first litter }{ }^{b}\end{array}$ & $8 / 14^{c}=57.14 \%$ & $15 / 17=88.24 \%$ & 0.10 & $6 / 6=100 \%$ & $2 / 10=20 \%$ & 0.0070 \\
\hline Size of first litter at birth & $8.1 \pm 0.6$ & $7.8 \pm 0.6$ & 0.75 & $8.8 \pm 0.7$ & $8.4 \pm 0.6$ & 0.65 \\
\hline Size of first litter at wean & $7.5 \pm 0.6$ & $7.3 \pm 0.6$ & 0.85 & $8.6 \pm 0.8$ & $8.2 \pm 0.6$ & 0.69 \\
\hline Size of second litter at birth & $7.6 \pm 0.6$ & $8.1 \pm 0.5$ & 0.50 & $6.3 \pm 0.9$ & $8.2 \pm 1.0$ & 0.20 \\
\hline Size of second litter at wean & $6.9 \pm 0.6$ & $7.4 \pm 0.5$ & 0.54 & $5.8 \pm 0.8$ & $6.0 \pm 0.9$ & 0.90 \\
\hline
\end{tabular}

${ }^{a}$ For most traits, values are least squares means \pm standard error from a general linear model including the effect of genotype (GLM procedure; SAS, ver 9.3). The number of days between the births of the first and second litters was analysed using failure time analysis with a log-logistic distribution, with females that did not produce a second litter included as right-censored observations (LIFEREG procedure), and the proportion of matings that produced a second litter was analysed using Fisher's Exact Test (FREQ procedure, chisq option). Analyses with nonparametric tests (Wilcoxon, Kruskal-Wallis; NPAR1WAY procedure) yielded qualitatively similar results

${ }^{b}$ In the first set of pairs, males were removed from females two weeks after the first litter was born, and therefore the females could only have given birth to a second litter within 35 days of the birth of the first litter. In contrast, pairs in the second set of matings were left together until the birth of the second litter 'One female died while delivering first litter and so was not included in this analysis

anti mouse IGFBP-5 (AF578; R\&D Systems). Membranes were visualized using the Odyssey infrared imaging system (Li-Cor Biosciences, Lincoln, NE) which allowed simultaneous quantification of IGFBP-5 and actin.

\section{Results and discussion Female fertility}

As expected, deletion of Pappa 2 increased ovarian levels of IGFBP-5 $\left(\mathrm{F}_{1,22}=20.89, \mathrm{P}<0.0001\right.$; Fig. 1$)$. However, all pairs gave birth to at least one litter, and there was no effect of Pappa2 deletion in females on the interval between pairing and the birth of the first litter, the interval between the births of the first and second litters, or litter size (Table 1). The lack of an effect of Pappa2 deletion is in contrast to the reduced litter size observed in Pappa deletion mice [15], suggesting different roles for IGFBP-4 (a substrate of PAPP-A, but not PAPP-A2) and IGFBP-5 (a substrate of both proteases) $[3,15]$ in ovarian function. Indeed, in mice it is thought that IGFBP-4 may induce atresia of follicles whereas IGFBP-5 expression decreases with follicular atresia [20]. While Pappa2 deletion was sufficient to elevate IGFBP-5 protein levels in whole ovaries, it was not sufficient to mimic the effects of transgenic Igfbp5 overexpression on fertility [16].

\section{Offspring size}

Birth weight and the weight of offspring at three weeks of age were analysed using repeated measures analyses since there were multiple pups for each female. Deletion of
Pappa2 in the female reduced offspring weight at birth $\left(F_{1,15}=17.92, P=0.0007\right.$; Fig. 2$)$, but there were no effects of parity (i.e., first vs. second litter; $\mathrm{F}_{1,8}=4.40, \mathrm{P}=0.07$ ). However, the effect of genotype was also significant when Pappa 2 was deleted in males $\left(\mathrm{F}_{1,7}=16.42, \mathrm{P}=0.005\right.$; Fig. 2; effect of parity: $F_{1,3}=1.88, P=0.26$ ), suggesting that the effect was due to offspring and not parental genotype. Offspring of deletion parents were heterozygous for the deletion, whereas offspring of controls were homozygous for an intact allele. Although the effects of Pappa2

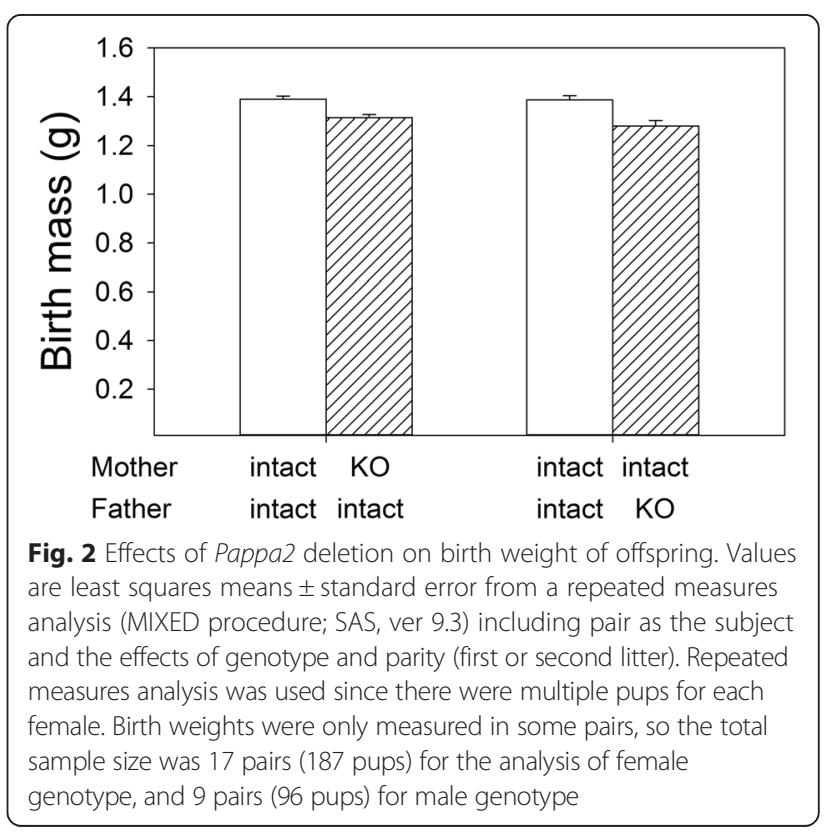




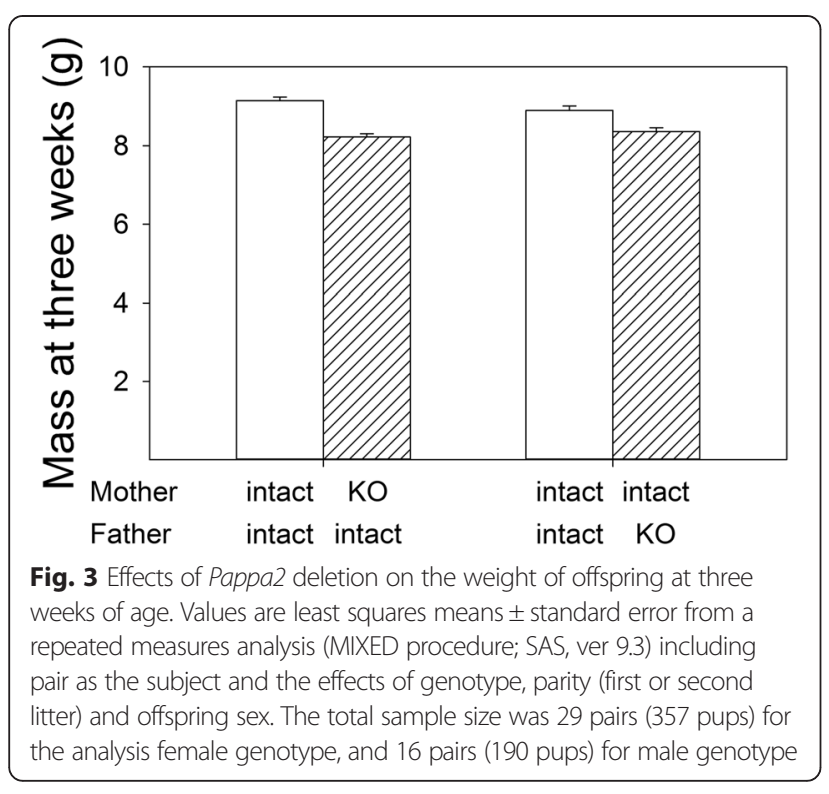

deletion are partially recessive, mice heterozygous for the Pappa2 deletion are slightly lighter than wild-type homozygotes [19].

As with birth weight, offspring weight at three weeks of age was reduced by Pappa 2 deletion in the female $\left(\mathrm{F}_{1,27}=56.58, \mathrm{P}<0.0001\right.$; Fig. 3$)$ or in the male $\left(\mathrm{F}_{1,14}=12.71, \mathrm{P}=0.0031\right.$; Fig. 3$)$, again suggesting that the effect was due to the genotype of the offspring. These analyses also included effects of parity and offspring sex, which were significant for analyses of Pappa2 deletion in females (parity: $\mathrm{F}_{1,19}=8.48, \mathrm{P}=0.0089$; sex: $F_{1,27}=18.52, P=0.0002$ ) and males (parity: $F_{1,9}=$ 11.32, $\mathrm{P}=0.0083$; sex: $\mathrm{F}_{1,14}=20.59, \mathrm{P}=0.0005$ ), with male offspring being heavier than female offspring. These results suggest that the deletion of Pappa2 did not increase IGFBP-5 levels sufficiently to achieve the reduced milk production observed in transgenic mice overexpressing Igfbp5 in the mammary gland [18].

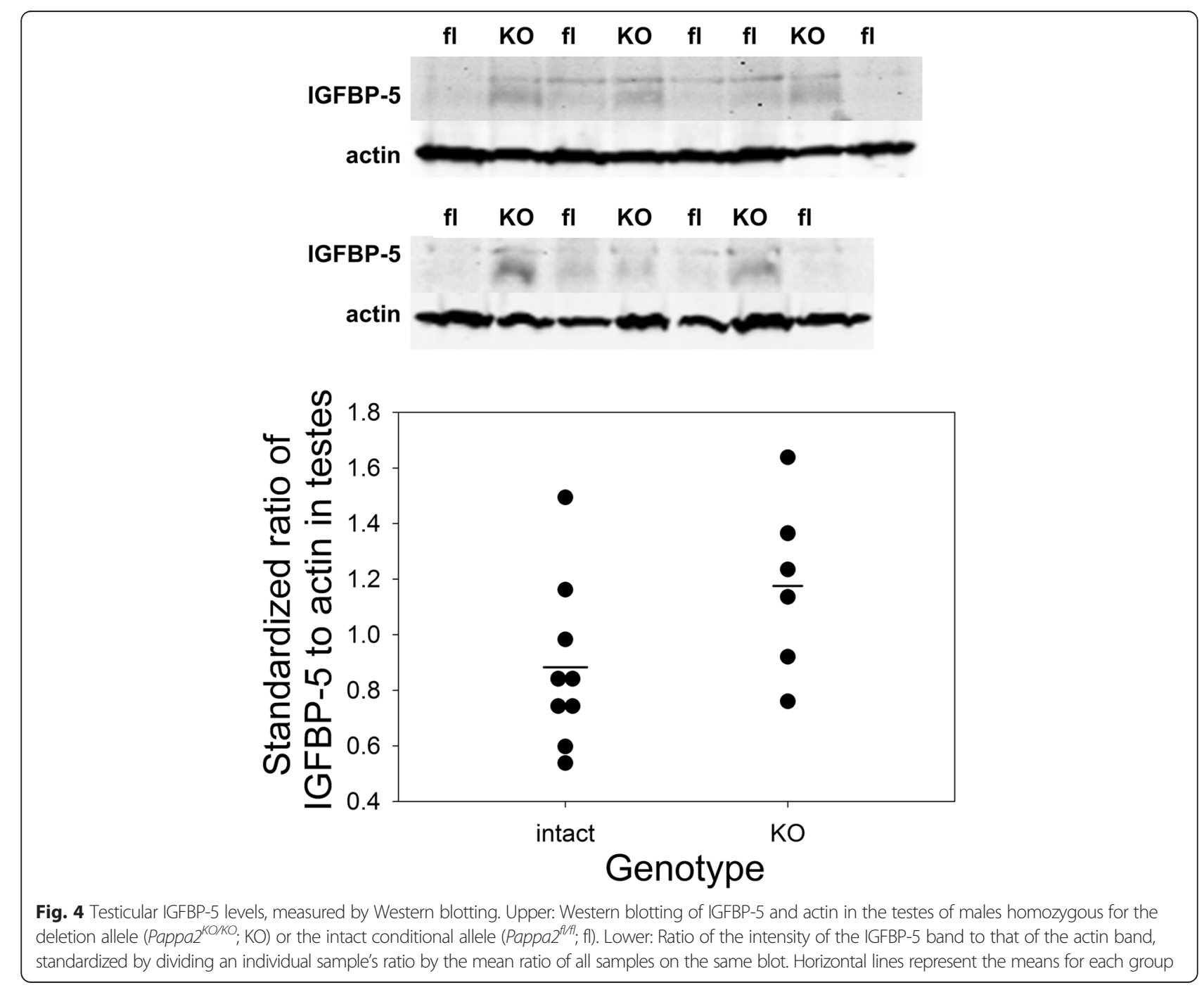




\section{Male fertility}

Because we examined reciprocal matings to control for the effect of offspring genotype, we were also able to examine the effects of Pappa2 deletion on male fertility. While there was no effect on litter size or the interval between pairing and the birth of the first litter, Pappa2 deletion in males significantly increased the interval between the births of the first and second litters (Table 1). This result is from a failure-time analysis that included females that did not produce a second litter as rightcensored observations. Therefore, this result could reflect females mated to Pappa 2 deletion males (a) taking longer to become pregnant, (b) being less likely to become pregnant a second time, or (c) having a higher probability of fetal resorption or spontaneous abortion. Females mated to Pappa 2 deletion males were less likely to become pregnant within two weeks of the birth of the first litter (and so give birth to a second litter within 35 days of the birth of the first litter; Table 1). However, even among females who did give birth to a second litter within 35 days of the birth of the first litter, there was a trend whereby females mated to Pappa 2 deletion males tended to have a longer interval between first and second litters $\left(\mathrm{F}_{1,6}=4.29, \mathrm{P}=0.08\right)$. It is not clear why Pappa 2 deletion in males affected the interval between first and second litters but not the interval between pairing and the birth of the first litter, although males may have become more susceptible to the effects of Pappa2 deletion as they aged.

The effect of Pappa2 deletion in males, i.e., increased time between litters without an effect on litter size, is similar to that of prostate removal [21]. Since the PAPPA2 substrate, IGFBP-5, is associated with decreased proliferation and/or increased apoptosis in the prostate [22-24], Pappa2 deletion would be expected to increase local IGFBP-5 levels and so decrease proliferation/ increase apoptosis in the prostate, leading to subfertility. IGFBP-5 in the prostate was not detectable by Western blotting (data not shown), but was detectable in the testes, and tended to be increased by Pappa 2 deletion, but the difference was not significant $\left(\mathrm{F}_{1,13}=3.36, \mathrm{P}=0.09\right.$; Fig. 4). While the influence of PAPP-A2 on male fertility may involve IGFBP-5 and the regulation of IGF availability, it has recently been suggested that PAPP-A2 may also act through IGFBP-5 independent pathways [25].

\section{Conclusions}

Pappa2 deletion had no effect on female fertility, in contrast to the effects of Pappa deletion or Igfbp5 overexpression. Deletion of Pappa2 had subtle effects on male fertility, increasing the interval between first and second litters but not the interval between pairing and the birth of the first litter. The mechanism underlying this effect on male fertility remains to be elucidated.

\section{Abbreviations}

IGF: Insulin-like growth factor; IGFBP: Insulin-like growth factor binding protein; PAPP-A: Pregnancy-associated plasma protein-A; SNP: Single nucleotide polymorphism.

\section{Competing interests}

The authors declare that they have no competing interests.

\section{Authors' contributions}

JKC designed the study, participated in animal and laboratory work, performed statistical analyses and drafted the manuscript. AYK, MDR and $\mathrm{SMH}$ performed the animal and laboratory work and provided input on the manuscript. All authors read and approved the final manuscript.

\section{Acknowledgements}

We thank Eva Wang, Kaitlyn Martel and Natalia Westervelt for assistance and Alex Fraser for advice and guidance. This work was supported by a NSERC Discovery Grant to JKC.

Received: 31 July 2015 Accepted: 16 September 2015

Published online: 29 September 2015

\section{References}

1. Mazerbourg S, Bondy CA, Zhou J, Monget P. The Insulin-like Growth Factor system: a key determinant role in the growth and selection of ovarian follicles? A comparative species study. Reprod Domest Anim. 2003;38:247-58.

2. Bunn RC, Fowlkes JL. Insulin-like growth factor binding protein proteolysis. Trends Endocrinol Metab. 2003;14:176-81.

3. Overgaard MT, Boldt HB, Laursen LS, Sottrup-Jensen L, Conover CA, Oxvig C. Pregnancy-associated plasma protein-A2 (PAPP-A2), a novel insulin-like growth factor-binding protein-5 proteinase. J Biol Chem. 2001;276:21849-53.

4. Wagner PK, Christians JK. Altered placental expression of PAPPA2 does not affect birth weight in mice. Reprod Biol Endocrin. 2010;8:90.

5. Wang J, Qiu Q, Haider M, Bell M, Gruslin A, Christians JK. Expression of pregnancy-associated plasma protein A2 during pregnancy in human and mouse. J Endocrinol. 2009;202:337-45.

6. Crosley EJ, Durland U, Seethram K, Macrae S, Gruslin A, Christians JK. FirstTrimester Levels of Pregnancy-Associated Plasma Protein A2 (PAPP-A2) in the Maternal Circulation Are Elevated in Pregnancies That Subsequently Develop Preeclampsia. Reprod Sci. 2014;21:754-60.

7. Wagner PK, Otomo A, Christians JK. Regulation of pregnancy-associated plasma protein A2 (PAPPA2) in a human placental trophoblast cell line (BeWo). Reprod Biol Endocrinol. 2011;9:48.

8. Christians JK, Hoeflich A, Keightley PD. PAPPA2, an enzyme that cleaves an insulin-like growth-factor-binding protein, is a candidate gene for a quantitative trait locus affecting body size in mice. Genetics. 2006;173:1547-53.

9. Christians JK, de Zwaan DR, Fung SHY. Pregnancy Associated Plasma Protein A2 (PAPP-A2) Affects Bone Size and Shape and Contributes to Natural Variation in Postnatal Growth in Mice. Plos One. 2013:8:e56260.

10. Conover CA, Boldt HB, Bale LK, Clifton KB, Grell JA, Mader JR, et al. Pregnancy-Associated Plasma Protein-A2 (PAPP-A2): Tissue Expression and Biological Consequences of Gene Knockout in Mice. Endocrinology. 2011;152:2837-44.

11. Luna-Nevarez P, Rincon G, Medrano JF, Riley DG, Chase Jr CC, Coleman SW, et al. Single nucleotide polymorphisms in the growth hormone-insulin-like growth factor axis in straightbred and crossbred Angus, Brahman, and Romosinuano heifers: Population genetic analyses and association of genotypes with reproductive phenotypes. J Anim Sci. 2011;89:926-34.

12. Hawken RJ, Zhang YD, Fortes MRS, Collis E, Barris WC, Corbet NJ, et al. Genome-wide association studies of female reproduction in tropically adapted beef cattle. J Anim Sci. 2012;90:1398-410.

13. Wickramasinghe S, Rincon G, Medrano JF. Variants in the pregnancyassociated plasma protein-A2 gene on Bos taurus autosome 16 are associated with daughter calving ease and productive life in Holstein cattle. J Dairy Sci. 2011;94:1552-8.

14. Luna-Nevarez P, Rincon G, Medrano JF, Riley DG, Chase Jr CC, Coleman SW, et al. Identification of one polymorphism from the PAPP-A2 gene associated to fertility in Romosinuano beef heifers raised under a subtropical environment. Revista Mexicana De Ciencias Pecuarias. 2012;3:185-200. 
15. Nyegaard M, Overgaard MT, Su Y, Hamilton AE, Kwintkiewicz J, Hsieh M, et al. Lack of Functional Pregnancy-Associated Plasma Protein-A (PAPPA) Compromises Mouse Ovarian Steroidogenesis and Female Fertility. Biol Reprod. 2010;82:1129-38.

16. Salih DAM, Tripathi G, Holding C, Szestak TAM, Gonzalez ML, Carter EJ, et al. Insulin-like growth factor-binding protein 5 (lgfbp5) compromises survival, growth, muscle development, and fertility in mice. Proc Natl Acad Sci U S A. 2004;101:4314-9.

17. Allan GJ, Beattie J, Flint DJ. The role of IGFBP-5 in mammary gland development and involution. Domest Anim Endocrinol. 2004;27:257-66.

18. Tonner E, Barber MC, Allan GJ, Beattie J, Webster J, Whitelaw CBA, et al. Insulin-like growth factor binding protein-5 (IGFBP-5) induces premature cell death in the mammary glands of transgenic mice. Development. 2002;129:4547-57.

19. Christians JK, Bath AK, Amiri N. Pappa2 deletion alters IGFBPs but has little effect on glucose disposal or adiposity. Growth Horm IGF Res. 2015;25:232-239.

20. Wandji SA, Wood TL, Crawford J, Levison SW, Hammond JM. Expression of mouse ovarian insulin growth factor system components during follicular development and atresia. Endocrinology. 1998;139:5205-14.

21. Pang SF, Chow PH, Wong TM. Role of the Seminal-Vesicles, Coagulating Glands and Prostate-Glands on the Fertility and Fecundity of Mice. J Reprod Fertil. 1979;56:129-32.

22. Nickerson T, Pollak M, Huynh H. Castration-induced apoptosis in the rat ventral prostate is associated with increased expression of genes encoding insulin-like growth factor binding proteins 2,3,4 and 5. Endocrinology. 1998;139:807-10.

23. Nickerson T, Huynh H. Vitamin D analogue EB1089-induced prostate regression is associated with increased gene expression of insulin-like growth factor binding proteins. J Endocrinol. 1999;160:223-9.

24. Thomas LN, Cohen P, Douglas RC, Lazier C, Rittmaster RS. Insulin-like growth factor binding protein 5 is associated with involution of the ventral prostate in castrated and finasteride-treated rats. Prostate. 1998;35:273-8.

25. Kjaer-Sorensen K, Engholm DH, Jepsen MR, Morch MG, Weyer K, Hefting LL, et al. Papp-a2 modulates development of cranial cartilage and angiogenesis in zebrafish embryos. J Cell Sci. 2014;127:5027-37.

\section{Submit your next manuscript to BioMed Central and take full advantage of:}

- Convenient online submission

- Thorough peer review

- No space constraints or color figure charges

- Immediate publication on acceptance

- Inclusion in PubMed, CAS, Scopus and Google Scholar

- Research which is freely available for redistribution 